\title{
Gultura.ion Por
}

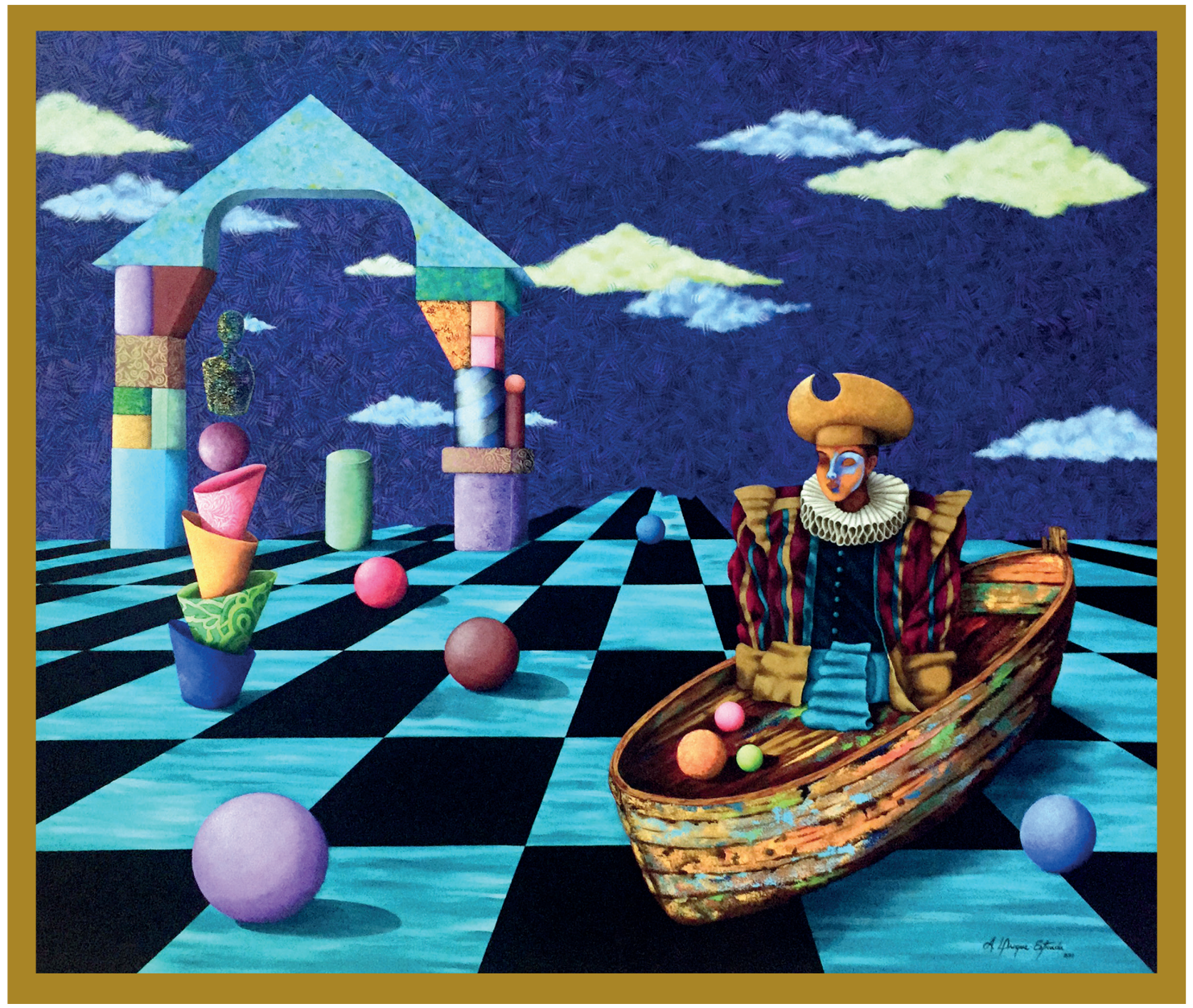

Título: Voyante - Técnica: Acrílico - Soporte: lienzo - Año: 2017 Medidas: $120 \mathrm{~cm}$ x $130 \mathrm{~cm}$ x $5 \mathrm{~cm}$

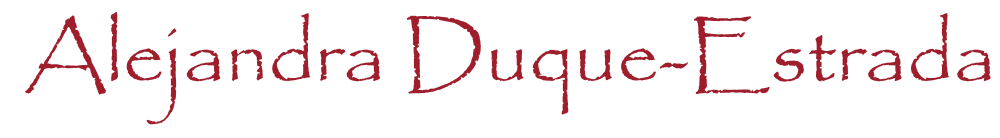

Esta serie de pinturas la estoy elaborando desde hace unos 4 años y el concepto simboliza la vida como un ajedrez, en el que nosotros somos las piezas en él, y la mano que nos mueve es la mano del destino, la mano de Dios, o la mano que se mueve por nuestras decisiones o la de alguien más, lo cual conlleva a una consecuencia. Las pinturas muestran escenarios con personajes y ambientes mágicos creados por mí, en pintura trabajo en la mayoría de los casos, en acrílico, con pastas para texturizar detalles, a veces uso aplicaciones de hoja de oro o resinas... El estilo, por ponerle alguno, va entre realismo mágico (según los colegas) y surrealismo mágico, a como yo he querido definirlo, ya que tengo elementos muy usados en surrealismo y por tratar de compararlo con algún estilo, me encontré identificada con el surrealismo de Giorgio de Chirico. Aunque al final yo, lo que he creado, luego de 20 años de estar pintando, es un estilo propio que no obedece a ningún tipo de arte predefinido, más que a mi propia creatividad.

Alejandra Duquestrada

Artista plástica

Diseñadora Gráfica 